Research Note

Journal of Extension Education

Vol. 29 No. 2, 2017

DOI:https: / / doi.org/10.26725/JEE.2017.2.29.5880-5884

\title{
Role of Mass Media in Changing the Attitude Level of Farmers towards Organic Farming in the Western Zone of Tamil Nadu
}

\author{
P. Sivaraj ${ }^{1}$ and H. Philip ${ }^{2}$
}

\begin{abstract}
The study aims to assess the role of mass media in changing the attitude level of farmers on organic farming. A sample of 180 certified organic farmers was selected from the districts of Coimbatore, Erode and Tiruppur, Tamil Nadu. Majority of the respondents in the study area had medium level of mass media exposure. Findings revealed that majority of the certified organic farmers was found to possess moderately favourable attitude towards organic farming, followed by highly favourable attitude towards organic farming. Different media were sought by the respondents for getting information on organic cultivation aspects. Even though most of the respondents were literates, limited availability of magazines, journals and periodicals related to organic and the problems on their subscription were acting as the limiting factors for accessing agricultural information. Leveraging traditional mass media and modern ICT technologies will help in the long run to increase the adoption levels among farming communities and help in devising and disseminating organic farming cultivation practices.
\end{abstract}

Keywords : Attitude; Mass media; Organic farmers

Media play a vital role in educating and enlightening the people and the government to protect and preserve natural resources in the interests of future generations and the limatic chaos. Sustainable Development is attained by protecting the environment in a judicious use of natural resources. In this regard, media plays a crucial role in creating awareness and bringing the positive behavioral change among people in climate change. Different media were sought by the respondents for getting information on agricultural aspects.
Now-a-days, every household have mass media like radio, television, newspaper etc., but the coverage of agricultural related by these sources are very limited when compared to other entertainment programmes. Again, though most of the respondents were functionally literates, limited availability of magazines, journals and periodicals related to agriculture and the problems on their subscription were acting as the limiting factors for gathering agricultural information from these sources too.

1. Assistant Professor (Agricultural Extension), RVS Agricultural College, Thanjavur and 2. Director of Extension Education, Tamil Nadu Agricultural University, Coimbatore - 641003 
Mass media play an important role in disseminating the farm technologies. Agricultural information are disseminated through magazines, newspaper, radio and television. Hence it becomes necessary to know about the level of mass media exposure.

Organic farming can be seen as an approach to agriculture where the aim is to create integrated, sustainable agricultural production systems. Conventional farming is based on the use of high yielding varieties of seeds, chemical fertilizer, irrigation water, pesticides etc. Whereas organic farming tends to satisfy the ever growing demand for food grains not only to fulfill the problem of food security but also to earn foreign exchange at the cost of environmental quality which cannot be sustainable in future.

In India, still farmers are not aware about the importance of organic farming. Promoting organic farming practices among the farming community in a large scale will be a promising strategy to face these challenges (Elavarasi and Ponnusamy, 2015). This paper discusses the role of mass media in changing the attitude of farmers towards organic farming among the certified organic farmers of western zone in Tamil Nadu.

\section{METHODOLOGY}

Ex post facto research design was adopted for the study. The Western zone of Tamil Nadu viz. Coimbatore, Erode and Tiruppur districts was selected purposively, as maximum number of organic farmers have registered under the category of individual certified organic farmers. Farmers were practising organic farming in different crops like coconut, banana, pulses and turmeric in the study area. A total of 180 certified organic farmers were selected for the study. A sample size of 60 organic farmers was considered for the study in each of the districts viz., Coimbatore, Erode and Tiruppur. In each district, three blocks were selected and in each block 20 certified organic farmers were selected through purposive random sampling method. A comprehensive semi structured interview schedule covering all aspects of organic farming practices was prepared. Each of the selected certified organic farmers were contacted personally and interviewed. The data collected were subjected to statistical analysis to get inferences.

\section{FINDINGS AND DISCUSSION}

\section{Mass Media Exposure}

It was found that more than half $(52.22 \%)$ of the certified organic farmers possessed medium level of mass media exposure followed by high (28.33\%) and low $(19.45 \%)$ levels. Certified organic farmers were found to be habituated readers of farm magazines like Uzavarin Valarum Velanmai which is published from Tamil Nadu Agricultural University, TV programmes and radio talks. Likewise listening to agricultural programmes in Doordarshan and other commercial television channels also motivated them to adopt organic farming. Moreover, 
newspapers have been publishing organic farming articles highlighting the importance of organic cultivation, marketing and success stories in regional languages. This might be the reason for medium to high level of mass media exposure among the certified farmers.

Table 1.

Distribution of the Respondents according to their Different Source/ form of Mass Media

$\mathrm{n}=180$

\begin{tabular}{|c|l|c|c|c|}
\hline \multirow{2}{*}{$\begin{array}{c}\text { S1. } \\
\text { No. }\end{array}$} & \multicolumn{1}{|c|}{ Particulars } & \multicolumn{3}{|c|}{ Certified organic farmers } \\
\cline { 2 - 5 } & Regularly & Occasionally & Never \\
\hline 1. & $\begin{array}{l}\text { Listening to agricultural } \\
\text { programmes in radio }\end{array}$ & $\begin{array}{c}51.11 \\
\text { (per cent) }\end{array}$ & $\begin{array}{c}26.68 \\
\text { (per cent) }\end{array}$ & $\begin{array}{c}22.21 \\
\text { (per cent) }\end{array}$ \\
\hline 2. & Reading newspapers & $\begin{array}{c}66.67 \\
\text { (per cent) }\end{array}$ & $\begin{array}{c}31.11 \\
\text { (per cent) }\end{array}$ & $\begin{array}{c}2.22 \\
\text { (per cent) }\end{array}$ \\
\hline 3. & $\begin{array}{l}\text { Reading farm magazines and } \\
\text { journals }\end{array}$ & $\begin{array}{c}47.78 \\
\text { (per cent) }\end{array}$ & $\begin{array}{c}37.78 \\
\text { (per cent) }\end{array}$ & $\begin{array}{c}14.44 \\
\text { (per cent) }\end{array}$ \\
\hline 4. & $\begin{array}{l}\text { Reading leaflets/ folders/ } \\
\text { pamphlets }\end{array}$ & $\begin{array}{c}33.34 \\
\text { (per cent) }\end{array}$ & $\begin{array}{c}41.66 \\
\text { (per cent) }\end{array}$ & $\begin{array}{c}25.00 \\
\text { (per cent) }\end{array}$ \\
\hline 5. & $\begin{array}{l}\text { Viewing agricultural programmes } \\
\text { in TV }\end{array}$ & $\begin{array}{c}75.55 \\
\text { (per cent) }\end{array}$ & $\begin{array}{c}22.22 \\
\text { (per cent) }\end{array}$ & $\begin{array}{c}2.23 \\
\text { (per cent) }\end{array}$ \\
\hline 6. & Attending agricultural meetings & $\begin{array}{c}60.00 \\
\text { (per cent) }\end{array}$ & $\begin{array}{c}28.88 \\
\text { (per cent) }\end{array}$ & $\begin{array}{c}11.12 \\
\text { (per cent) }\end{array}$ \\
\hline 7. & Demonstrations & $\begin{array}{c}47.77 \\
\text { (per cent) }\end{array}$ & $\begin{array}{c}38.89 \\
\text { (per cent) }\end{array}$ & $\begin{array}{c}13.34 \\
\text { (per cent) }\end{array}$ \\
\hline 8. & Attending field days & $\begin{array}{c}32.22 \\
\text { (per cent) }\end{array}$ & $\begin{array}{c}41.66 \\
\text { (per cent) }\end{array}$ & $\begin{array}{c}26.12 \\
\text { (per cent) }\end{array}$ \\
\hline 9. & Watching agricultural films & $\begin{array}{c}27.77 \\
\text { (per cent) }\end{array}$ & $\begin{array}{c}38.89 \\
\text { (per cent) }\end{array}$ & $\begin{array}{c}33.34 \\
\text { (per cent) }\end{array}$ \\
\hline 10. & Viewing exhibitions & $\begin{array}{c}16.67 \\
\text { (per cent) }\end{array}$ & $\begin{array}{c}7.78 \\
\text { (per cent) }\end{array}$ \\
\hline
\end{tabular}


From Table 1 it is revealed that majority $(51.11 \%)$ of the respondents are regularly listening to agricultural programmes in radio. The farmers were listening to radio programmes predominantly during evening hours. From the result we infer that radio is still one of the powerful media used by the farming community. Majority (66.67 $\%)$ of the respondents were reading newspapers regularly followed by occasionally (31.11\%) and never (2.22 $\%)$. The farmers mostly read the regional news papers for agricultural information. Nearly half $(47.77 \%)$ of the respondents regularly read farm magazines and journals to know the recent agricultural technologies, success stories and new trends in agriculture. The farm magazines such as Uzhavarin Valarum Velanmai of TNAU, Pasumai Vikatan \& Uzhavar Osai (All Tamil farm magazines) were subscribed by the respondents. Moreover, $41.66 \%$ of the occasionally reading leaflets, folders and pamphlets for form information.

Table 1 shows larger difference in viewing agricultural programmes in TV. Majority $(75.55 \%)$ of the respondents were regularly viewing agricultural programmes in TV. The agricultural programmes broadcast by Doordarshan and Makkal TV were mostly viewed by the respondents.

\section{Attitude of Farmers towards Organic Farming}

It could be inferred from Table 2 that majority $(70.00 \%)$ of the certified organic farmers were found to possess moderately favourable attitude towards organic farming, followed by highly favourable (18.33\%) and less favourable $(11.67 \%)$ attitude towards organic farming.

Table 2.

Distribution of Respondents according to Attitude towards Organic Farming

$(\mathrm{n}=180)$

\begin{tabular}{|c|l|r|r|}
\hline $\begin{array}{r}\text { S1. } \\
\text { No. }\end{array}$ & \multicolumn{1}{|c|}{ Category } & Number & $\begin{array}{c}\text { Percen } \\
\text { tage }\end{array}$ \\
\hline 1. & Less favourable & 21 & 11.67 \\
\hline 2. & $\begin{array}{l}\text { Moderately } \\
\text { favourable }\end{array}$ & 126 & 70.00 \\
\hline 3. & $\begin{array}{l}\text { Highly } \\
\text { favourable }\end{array}$ & 33 & 18.33 \\
\hline & Total & 180 & 100.00 \\
\hline
\end{tabular}

Majority (70.00\%) of the organic farmers had moderately favourable attitude towards organic farming. The mass media exposure helps the farmers in understanding the nature of organic farming \& its importance. Moderate to higher level of mass media exposure could be the probable reason for the farmers to possess moderate to highly favourable attitude towards organic farming.

In conclusion, limited sources of mass media coverage information related to organic cultivation and importance, hindered not only the attitude level of the respondents but also adoption level 
of organic farming practices among farmers. There is an urgent need for creating effective and specific mass communication strategies for organic farming and extension activities among certified organic farmers of Tamil Nadu. It would be pertinent to propose to the policy makers, to draw new policies with a view to provide necessary skills to pursue organic practices through mass media.

\section{REFERENCES}

Elavarasi, M \& Ponnusamy, K. A. (2015). Reasons for Resorting to Organic Farming and Advantages Perceived by the Organic Farmers. Journal of Extension Education. 27 (3). 5485-5493. 